International Journal of Engineering \& Technology, $7(3.20)(2018) 398-401$
International Journal of Engineering \& Technology
SPC
Website: www.sciencepubco.com/index.php/IJET
Research paper

\title{
Reserve Potential Sandy Clay as a Raw Materials Cement Village Hambalang, County Citeureup District Bogor Province Jawabarat - Indonesia
}

\author{
Teti Syahrulyati , Singgih Irianto and Yusup Suhendi \\ Universitas Pakuan - Pakuan street PO.Box 432 Bogor-Indonesia \\ *Corresponding Author Email: tetisyahrulyati@unpak.ac.id
}

\begin{abstract}
Administratively the research area is in Hambalang Village Kec. Citeureup Kab. Bogor West Java, travel time to the location of the city of Bogor for 60 minutes by motor vehicle, the area of research around 1732 ha. The existence of sedimentary rocks in the form of limestones and batulempung is utilized by one cement factory in Indonesia as raw material of cement. Measurement and sampling is done to know the amount of measured reserves. Analysis of the content of oxide compounds is done by AAS method to determine the levels of the compounds they contain. The results of the calculations of $\mathrm{SiO}_{2}$ and $\mathrm{Al}_{2} \mathrm{O}_{3}$ are abbreviated as $(\mathrm{AI}=$ alumina Index) and the pattern of distribution is made with the aim that the mining process becomes effective, efficient and directed. The method use to principle of the concept of three-point method is used as the basis for making contours of the distribution of compounds contained. Drilling data, chemical analysis, DTM (Digital Terain Modeling) data and Isoline data generated were obtained using Autoclan 3D map 2015 and Autoplan Geomo. The calculation of reserves (AI / Alumina Indek $3.21-3.70 \%$ ) with the highest reserves 1,643,814 Tones. The smallest reserve (AI quality $5.00-6.01 \%$ ) is 199,980 Tones. This research resulted in a map of the distribution of Alumina index, so as to facilitate the extraction and very helpful in executing the area / block that must be mined.
\end{abstract}

Keywords: Reserve Potential, Sandy Clay, Cement Raw Materials

\section{Introduction}

\subsection{Background}

Bogor Regency has an area of about $2,301.95 \mathrm{~km}^{2}$, or equivalent to $5.19 \%$ the total area of West Java Province can be reached from the capital of Jakarta for 30 minutes to get to the research location taken within 60 minutes. It has a very wide range of landscapes ranging from terrain topography to mountains that are influenced by the geological conditions of the type forming rock and the pattern of tectonic developments that have taken place. The study area is located in Pasir Gadung Block - Hambalang quarry in Hambalang village, county Citeureup, districk Bogor West Java, generally the rock type in this region of sedimentary rock (limestone and sandstone clay / sandy clay) with a large enought expanse so interesting and necessary to do research considering this quarry region of one cement factory in Indonesia. Knowing the content of Alumina Index $\left(\mathrm{SiO}_{2} / \mathrm{Al}_{2} \mathrm{O}_{3}\right)$ and speading pattern and distribution model of Alumina Index generated will be very helpful in calculation of reserve potential Alumina Index, so that mining process becomes effective, efficient and directed. Alumina or aluminum oxide $\left(\mathrm{Al}_{2} \mathrm{O}_{3}\right)$ in its various levels of purity is used more often than any other advanced ceramic material and cement is anything that binds, particularly a substance made of burned lime, clay, sand and water to make mortar or sand, water and gravel to make concrete.

\subsection{Problem Formulation and Limitations}

The scope of this research is to map the quality distribution of Alumina Index and to make three dimensional geological section modeling in Hambalang quary location, especially in Pasir Gadung Block using drill data.

The research is focused on making Zonation model of Alumina Index distribution and geological cross section model in Pasir Gadung Block, Hambalang, using two types of data, namely; Primary data is Raster Drilling and secondary data is Core Drilling.

\subsection{Research Objectives}

Knowing the three dimensional form of Alumuna Index distribution in Pasir Gadung Block, Hambalang.

Knowing the detailed three-dimensional shape of geology in Pasir Gadung Block, Hambalang.

\subsection{Location, Area and Acsesibility}

The research area is administratively entered into Hambalang Village, couty Citeureup districk Bogor West Java, can be accessed by any type of two-wheeled vehicles or four wheels, the required to go to the research area of Citeureup for 30 minutes the research area is about $1,732 \mathrm{Ha}$. 


\subsection{Research Area}

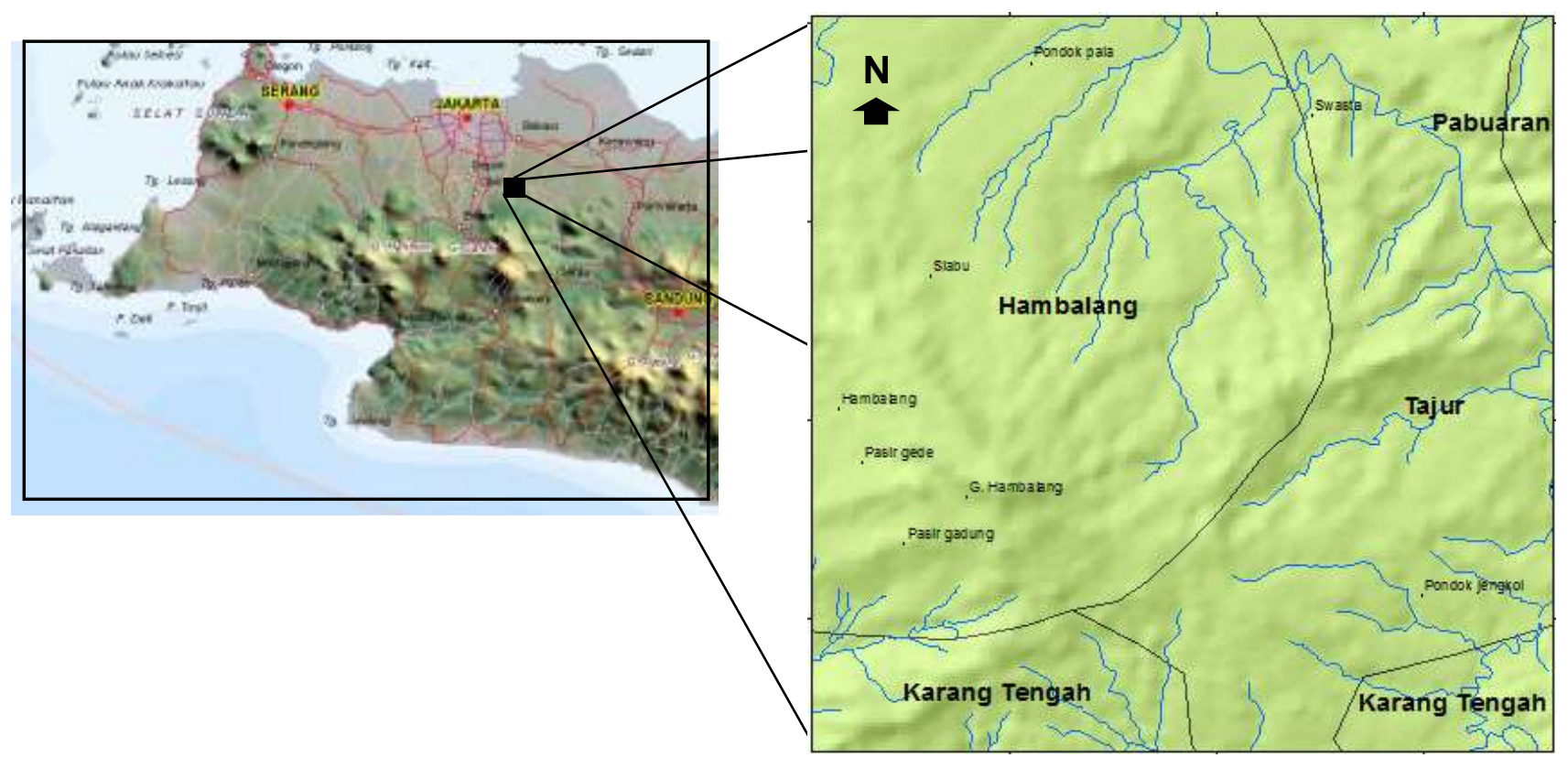

Figure 1: Research Sites

\section{Research Methods}

The three-point method is used as the basis for making the contour spread of Aluminum Index. In the making of distribution model, there are two data that being used as primary data and secondary data. The primary data is collected from Dust Sampling / Raster Drilling which includes (Sajad Ahmad, 2013); the determination of drilling location point, the depth of sampling, and the total drilling depth of each point. Depending on the needs, the exact point of sampling location is selected in randomly or systematically fashion. Figure 2 and 3 show the ruster drilling and core drilling respectively.

The scope of this research is to map the quality distribution of Alumina Index [2] and to make three dimensional geological sections modeling in Hambalang quary, especially in Pasir Gadung Block, by using its drill data. The research area is administratively located in Desa Hambalang, Kecamatan Citeureup, Kabupaten Bogor, Jawa Barat, and can be accessed with two-wheeled or four wheeled vehicles, with 30 minutes stands as the estimated time arrival from Citeureup. The research area is about $1,732 \mathrm{Ha}$.

The research is focused on making zonation model of Alumina Index distribution and geological cross section model in Pasir Gadung Block, Hambalang, by using two types of data, namely; primary data of Raster Drilling and secondary data of Core Drilling.

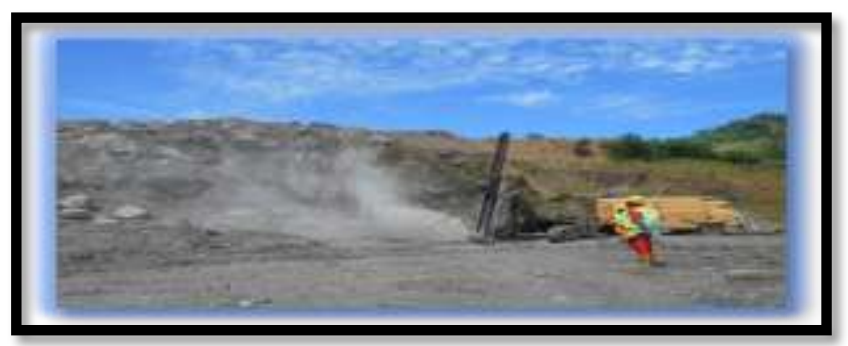

Figure: 2: Aktivitys drilling (Raster Drilling)

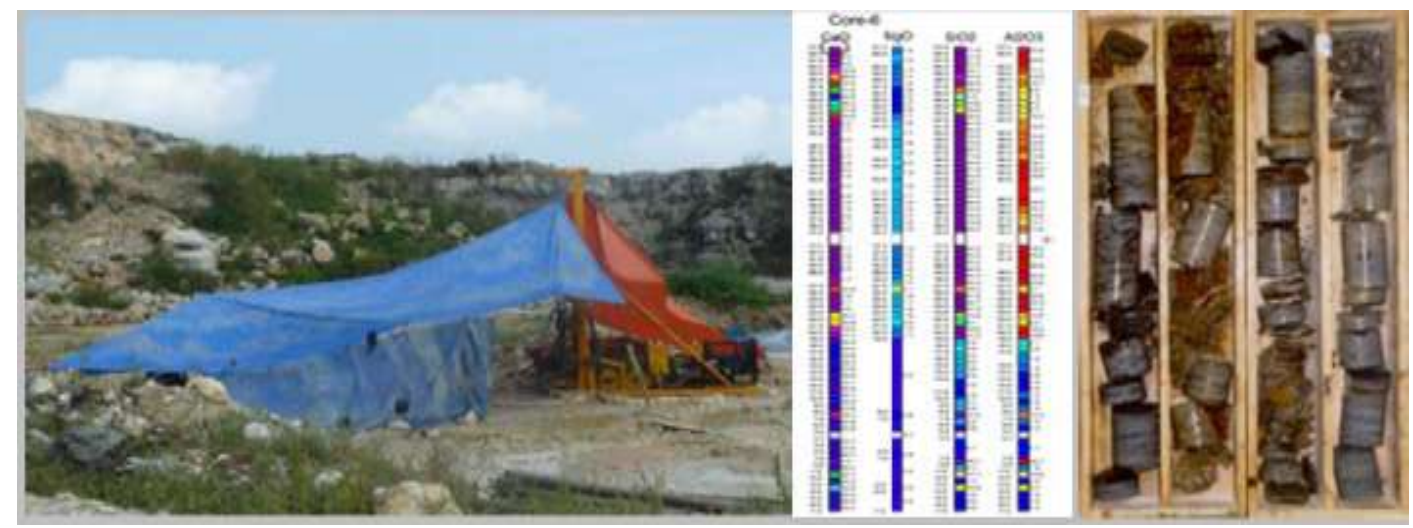

Figure3: Aktivitys drilling, result and Core Drilling

The Secondary data is collected through the existing Core Drilling data and drilling results. This data is being used to form the pattern of Alumina Index distribution chemical composition (the number of silica value, divided by the amount of alumina value). At the stage of making the distribution map (mine modeling blocks) the data that being prepared are; the drilling database (table.1), chemical analysis database (Chandana Sukesh,2012), DTM data and Isoline data, by using the software of Autocad 3D map 2015 and Autoplan Geomo software. 
The resulting Mine Model block from this research is a depiction of dimensional perspective that serves as information on the direction of mining and the age of mine. The analysis chemical composisition use to AAS (Atomic Absorption spectroscopy) is a spectroanalytical procedure for the quantitative determination of chemical elements using the absorption of optical radiation (light) by free atoms in the gaseous state.or X-Rd (X-ray difracto meter)method.

The content of oxide compounds analyzed are $\mathrm{SiO}_{2}, \mathrm{Al}_{2} \mathrm{O}_{3}, \mathrm{Fe}_{2} \mathrm{O}_{3}$, $\mathrm{CaO}$ and $\mathrm{MgO}$, whereas in the utilization of this sandy clay calculated is the content of Silica Dioxide compared to the content of Alumina trioxide $\left(\mathrm{SiO}_{2} / \mathrm{Al}_{2} \mathrm{O}_{3}=\mathrm{AI}\right.$, Alumina Index $)$ standard grade used in this factory is $3.5 \%$.

Tabel 1: Example Results of Core Drilling

\begin{tabular}{|c|c|c|c|c|c|}
\hline 4 & A & B & C & D & $E$ \\
\hline 1. & DrillNr & Easting & Northing & Height & Finaldepth_m \\
\hline 2 & RPG_11 & 711229 & 9276083 & 354.26 & 10.00 \\
\hline 3 & RPG 18 & 711056 & 9276111 & 336.25 & 10.00 \\
\hline 4 & RPG 20 & 711007 & 9276120 & 335.36 & 10.00 \\
\hline 5 & RPG 21 & 710958 & 9276128 & 336.04 & 10.00 \\
\hline 6 & RPG 23 & 710908 & 9276136 & 337.64 & 10.00 \\
\hline 7 & RPG 24 & 710859 & 9276144 & 343.35 & 10.00 \\
\hline 8 & RPG 28 & 711307 & 9276095 & 358.79 & 10.00 \\
\hline 9 & RPG_30 & 711258 & 9276103 & 353.81 & 10.00 \\
\hline 10 & RPG_32 & 711208 & 9276111 & 350.14 & 10.00 \\
\hline 11 & RPG 34 & 711159 & 9276120 & 345.34 & 10.00 \\
\hline 12 & RPG_58 & 711114 & 9276152 & 340.52 & 10.00 \\
\hline 13 & RPG_60 & 711065 & 9276161 & 336.22 & 10.00 \\
\hline 14 & RPG_62 & 711015 & 9276169 & 332.97 & 10.00 \\
\hline
\end{tabular}

\section{Results and Discussion}

By using the equation $\mathrm{AI}=$ the number of silica values divided by the number of alumina values, it can be seen the value of Alumina Index from each sample point. Increas content Alumina Index value is strongly influenced by the content silica contained in the rock. The high levels of silica produced depend on the diagenesis of the rock. Usually high levels of silica content caused by acidic stones or caused by the deposition of marine environments that are rich in silica dissolution of carbonaceous rocks [4]. The results of the Index alumina calculations at the study sites are listed at the Table 2 below.

Table 2: Chemical Analysis Results and AI calculation methods

\begin{tabular}{|c|c|c|c|c|c|c|c|}
\hline Start & End & $\overline{\mathrm{SiO} 2}$ & $\mathrm{~A} 12 \mathrm{O3}$ & $\mathrm{Fe} 2 \overline{\mathrm{O}} 3$ & $\overline{\mathrm{C}} \mathrm{a} \overline{\mathrm{O}}$ & $\mathrm{MgO}$ & $\overline{\mathrm{Al}}$ \\
\hline 0.00 & 2.00 & 78.26 & 4.64 & 4.69 & 1.15 & 0.71 & 16.87 \\
\hline 2.00 & 4.60 & 80.85 & 4.49 & 0.80 & 0.65 & 0.26 & 18.01 \\
\hline 4.60 & 5.00 & 78.84 & 4.43 & 4.77 & 0.56 & 0.97 & 17.80 \\
\hline 5.00 & 7.00 & 59.40 & 17.90 & 6.38 & 0.74 & 1.57 & 3.32 \\
\hline 7.00 & 9.00 & 59.35 & 18.13 & 6.38 & 0.76 & 1.62 & 3.27 \\
\hline 9.00 & 11.00 & 58.49 & 18.41 & 6.53 & 0.79 & 1.63 & 3.18 \\
\hline 11.00 & 13.00 & 56.66 & 18.54 & 7.67 & 0.82 & 1.72 & 3.06 \\
\hline 13.00 & 15.00 & 57.88 & 19.36 & 6.63 & 0.76 & 1.67 & 2.99 \\
\hline 15.00 & 17.00 & 58.11 & 19.03 & 6.53 & 0.73 & 1.64 & 3.05 \\
\hline 17.00 & 19.00 & 57.49 & 18.72 & 7.17 & 0.75 & 1.70 & 3.07 \\
\hline 19.00 & 21.00 & 59.48 & 17.61 & 6.22 & 0.83 & 1.58 & 3.38 \\
\hline 21.00 & 23.00 & 57.89 & 19.84 & 6.56 & 0.68 & 1.67 & 2.92 \\
\hline 23.00 & 25.00 & 58.09 & 17.77 & 7.21 & 0.72 & 1.64 & 3.27 \\
\hline 25.00 & 27.00 & 60.08 & 18.00 & 6.05 & 0.65 & 1.54 & 3.34 \\
\hline 27.00 & 29.00 & 60.21 & 17.85 & 6.14 & 0.69 & 1.54 & 3.37 \\
\hline 29.00 & 30.00 & 58.75 & 18.54 & 6.35 & 0.77 & 1.59 & 3.17 \\
\hline
\end{tabular}

To facilitate the depiction, the results of this analysis are divided into 7 classes Alumina Index (AI) [2] and each of its class is given color symbol as listed:

- $\mathrm{AI}=0.00-3.20$

3.70

(blue)

(dark blue )

$\mathrm{AI}=3.20-$

- $\quad \mathrm{AI}=3.70-4.40$

$5.00 \quad$ (green)

(yellow)

- $\mathrm{AI}=5.00-6.00$ (orange)

(brown)
$\mathrm{AI}=4.40-$

$\mathrm{AI}=6.00-7.00$
- $\quad \mathrm{AI}=7.00-100$ (red)

Following is the map of AI distribution from Hambalang Quarry Pasir Gadung Block seen from bench level $300 \mathrm{~m}$. It is showing the pattern of AI quality distribution and sandy clay reserve from each of its cross sections can be calculated according to the quality of Alumina Index. 


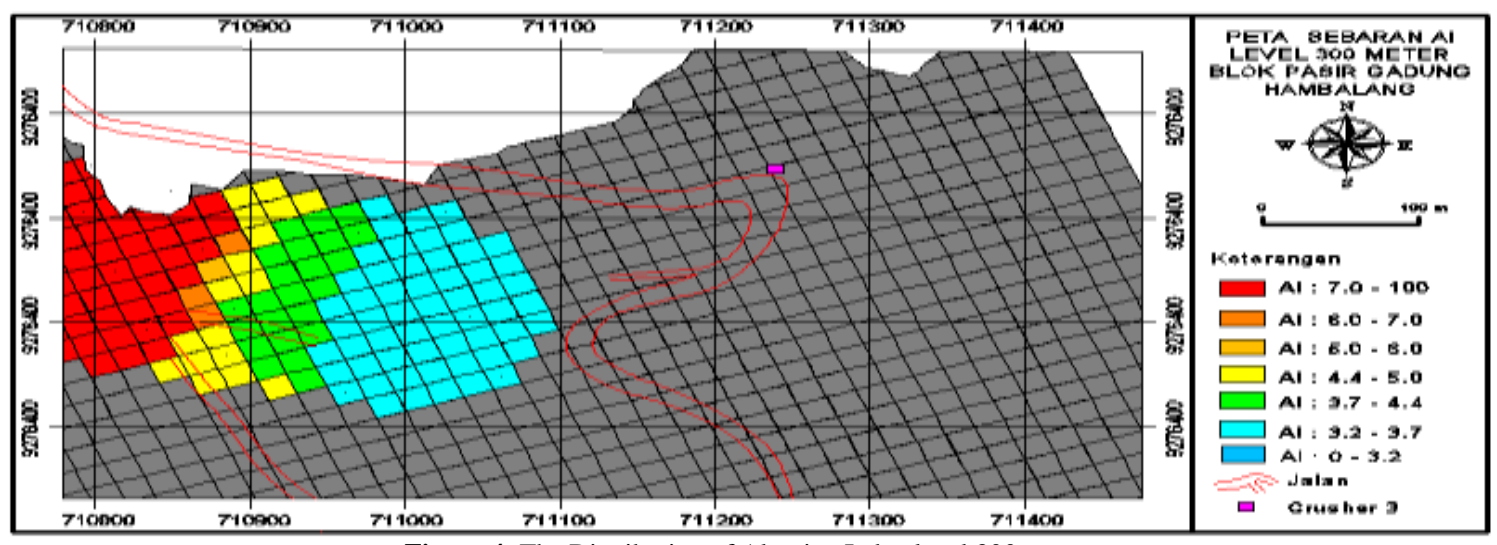

Figure 4: The Distribution of Alumina Index level 300 meter

In this following Table 3, the amount of Sandy clay quantity is shown generated from the location of Pasir Gadung block as follows.

Tabel 3: Quality Alumina Index $\left(\mathrm{SiO}_{2} / \mathrm{Al}_{2} \mathrm{O}_{3}\right)$ - Pasir Gadung Block

\begin{tabular}{|c|c|c|c|c|c|c|c|c|}
\hline \multirow{2}{*}{ No. } & \multirow{2}{*}{ Level (meter) } & \multicolumn{7}{|c|}{ Quality $\mathrm{AI}=\left(\mathrm{Si}_{2} \mathrm{O}_{3} / \mathrm{Al}_{2} \mathrm{O}_{3}\right.$ Ton $)$} \\
\hline & & $0.00-3.20$ & $3.21-3.70$ & $3.71-4.40$ & $4.41-5.00$ & $5.00-6.00$ & $6.00-7.00$ & $7.00-100$ \\
\hline 1 & 300 & 0 & 201654 & 82773 & 61173 & 3591 & 10780 & 131751 \\
\hline 2 & 305 & 0 & 203184 & 76986 & 46575 & 3591 & 10773 & 82773 \\
\hline 3 & 310 & 0 & 142542 & 17955 & 16200 & 30798 & 28449 & 151227 \\
\hline 4 & 315 & 219096 & 199512 & 14400 & 14400 & 14400 & 28800 & 148617 \\
\hline 5 & 320 & 239220 & 158400 & 50400 & 36000 & 50400 & 32400 & 145584 \\
\hline 6 & 325 & 422874 & 104400 & 21600 & 18000 & 32400 & 21600 & 58059 \\
\hline 7 & 330 & 38043 & 355617 & 113247 & 21600 & 10800 & 25200 & 80559 \\
\hline 8 & 335 & 27000 & 260505 & 130509 & 12600 & 18000 & 10800 & 100980 \\
\hline 9 & 340 & 137970 & 18000 & 18000 & 18000 & 36000 & 50400 & 205227 \\
\hline \multicolumn{2}{|r|}{ Total } & 1084203 & 1643814 & 525870 & 244548 & 199980 & 219202 & 1245915 \\
\hline
\end{tabular}

From this table, the quantity of Sandy Clay based on AI content can be concluded as:

- Content AI $3.21-3.70: 1,643,814$ Tones

- Content AI $7.01-100: 1,245,915$ Tones

- Content AI $0.00-3.20: 1,084,203$ Tones

- Content AI 3.71-4.40: 525,870 Tones

- Content AI 4.41-5.00: 244,548 Tones

- Content AI 6.00-7.00: 219,202 Tones

- Content AI 5.00-6.01: 199,980 Tones

The quality of (AI 3.21 - 3.70) stands as the most AI qualification, measured in 1,643,814 Tones, while the smallest is (AI 5.00 - 6.01) in the quantity of 199,980 Tones.

\section{Conclusion}

By applying Dust Sampling / Raster Drilling as primary data, the results that were obtained are being used to take sampling at a certain depth, and each sample that were obtained are being analyzed on its chemical element content.

By knowing the chemical element of $\mathrm{SiO}_{2}$ and $\mathrm{Al}_{2} \mathrm{O}_{3}$, the Alumina Index value can be acknowledge. The Alumina Index is used as a classification standard [3] which furthermore are being used as a model AI distribution pattern for each class that can be made in three dimension and its calculated tonnage.

With the discovery of the tonnage and its spreading pattern, the mining direction can be more directed and the mining location can be placed according to the required level.

The tonnage and spreading pattern are known then the direction of mining can be determined more directed and the mining location can be determined according to the required level. The amount of reserves and the amount of needs is known then the life of the mine can be determined.

\section{Reference}

[1] Aydoğan, N.A., Ergün, L. and Benzer, H., 2006. High pressure grinding rolls (HPGR) applications in the cement industry. Minerals Engineering, 19(2), pp.130-139.
[2] Kendall \&Tucker, 1973; Kendall, 1985; Aubrecht et al., 2009. The characteristics of the spar are reminiscent of the void filling cement, radiaxial fibrous calcite.

[3] Mallikarjun Ganjigatti1, Kashinath B. R.2, K. B. Prakash3., 2015. Effect of Replacement of Cement by Different Pozzolanic Materials on Heat of Hydration and Setting Time of Concrete. International Journal of Environmental \& Agriculture Research (IJOEAR) (Vol1, Issue-4,August- 2015)

[4] Manassidis, I. and Gillan, M.J., 1994. Structure and energetics of alumina surfaces calculated from first principles. Journal of the American Ceramic Society, 77(2), pp.335-338.

[5] Peelen, J.G.J. and Metselaar, R., 1974. Light scattering by pores in polycrystalline materials: Transmission properties of alumina. Journal of Applied Physics, 45(1), pp.216-220.

[6] Rasul, M.G., Widianto, W. and Mohanty, B., 2005. Assessment of the thermal performance and energy conservation opportunities of a cement industry in Indonesia. Applied thermal engineering, 25(17), pp.2950-2965.

[7] Xiao, S., Drachev, V.P., Kildishev, A.V., Ni, X., Chettiar, U.K., Yuan, H.K. and Shalaev, V.M., 2010. Loss-free and active optical negative-index metamaterials. Nature, 466(7307), pp.735-738. 